\title{
Pengembangan Sistem Inspeksi Digital Berbasis Macro VBA Excel Dengan Metode Failure Mode And Effects Analysis (FMEA)
}

\section{Development of VBA Excel Macro-Based Digital Inspection System Using the Failure Mode And Effects Analysis (FMEA) Method}

\author{
Haudhi Alfi Yasin, Rianita Puspa Sari* \\ Jurusan Teknik Industri, Fakultas Teknik, Universitas Singaperbangsa Karawang \\ Jl. HS. Ronggo Waluyo, Puseurjaya, Kec.Telukjambe Timur, Kab.Karawang,Jawa Barat 41361 \\ Email: haudhi.alfiyasin17010@student.unsika.ac.id, rianita.puspasari@ft.unsika.ac.id
}

\begin{abstract}
ABSTRAK
Proses pemeriksaan akhir pada perusahaan manufakur merupakan aktivitas pemeriksaan yang dilakukan sebelum produk akan dikirim ke customer. Perkembangan komputerisasi dalam perusahaan merupakan kebutuhan pada saat ini untuk menjalankan aktivitas dalam perusahaan salah satunya perancangan dan pengembangan sistem inspeksi digital. Failure Mode and Effects Analysis (FMEA) merupakan salah satu metode yang dapat dilakukan dalam perbaikan kinerja suatu bisnis dan komponen di dalamnya. FMEA dapat melakukan analisis kesalahan yang akan terjadi pada suatu aktivitas pekerjaan dengan melakukan rating severity, occurrence dan detection untuk menghasilkan nilai Risk Priority Number (RPN). Sehingga, dapat diusulkan perbaikan dari tiap proses untuk mengurangi nilai RPN. Penelitian ini bertujuan untuk menganalisa kesalahan yang mungkin terjadi pada tiap proses pemeriksaan akhir dan usulan perbaikannya dengan menggunakan metode FMEA. Kemudian, dilakukan perancangan sistem inspeksi digital dengan menggunakan Macro VBA Excel. hasil penelitian dengan analisis FMEA ini didapatkan nilai RPN awal pada pekerjaan inspeksi akhir adalah 1019, dengan rekomendasi perbaikan nilai RPN berkurang menjadi 542. ini berarti berkurangnya tingkat kesalahan setelah dilakukan perancangan sistem inspeksi dengan aplikasi Macro VBA Excel. Selain nilai RPN yang berkurang, aplikasi ini juga dapat menghemat waktu pekerjaan dan mengurangi pemakaian kertas di perusahaan.
\end{abstract}

Kata Kunci: pemeriksaan akhir, sistem inspeksi, Failure Mode and Effects Analysis (FMEA), Macro VBA Excel

\begin{abstract}
The final inspection process at a manufacturing company is an inspection activity carried out before the product will be sent to the customer. The development of computerization in companies is a necessity at this time to carry out activities within the company, one of which is the design and development of a digital inspection system. Failure Mode and Effects Analysis (FMEA) is a method that can be used to improve the performance of a business and its components. FMEA can analyze errors that will occur in a work activity by rating severity, occurrence and detection to generate a Risk Priority Number (RPN) value. Thus, it can be proposed that improvements of each process to reduce the value of the RPN. This study aims to analyze errors that may occur in each final inspection process and to suggest improvements using the FMEA method. Then, the design of a digital inspection system is carried out using Macro VBA Excel. The results of this research with FMEA analysis showed that the initial RPN value in the final inspection work was 1019, with a recommendation to improve the RPN value reduced to 542. This means that the error rate is reduced after designing the inspection system with the Macro VBA Excel application. In addition to the reduced RPN value, this application can also save work time and reduce paper usage in the company.
\end{abstract}

Keywords: final inspection, inspection system, Failure Mode and Effects Analysis (FMEA), Macro VBA Excel

\section{Pendahuluan}

Kualitas adalah suatu ukuran seberapa jauh suatu produk memenuhi persyaratan atau spesifikasi kualitas yang telah ditetapkan (Iswanto et al., 2013). Proses produksi yang memperhatikan kualitas akan menghasilkan produk yang bebas dari kerusakan
(Windarti, 2014). Salah satu upaya untuk menjaga kualitas produk khususnya pada perusahaan manufaktur adalah dengan melakukan serangkaian pengendalian kualitas (Sari \& Purnawati, 2018)

Pengendalian kualitas merupakan aktivitas untuk menjaga, mengarahkan, mempertahankan dan memuaskan tuntutan konsumen secara maksimal 
(Lusiana, 2007). Pemeriksaan akan meminimasi kerusakan produk (Sugandi \& Dewi, 2018). Suatu perusahaan dikatakan baik apabila memiliki suatu sistem produksi yang baik dengan proses yang terkendali, dalam hal ini adalah pengendalian kualitas (Sunardi \& Suprianto, 2015). Seiring perkembangan ilmu pengetahuan dan teknologi (iptek) yang semakin maju, komputerisasi telah menjadi kebutuhan bagi perusahaan (Handayani et al., 2013). Selain itu, komputerisasi sistem juga dapat mengurangi waktu proses suatu aktivitas dan meningkatkan produktivitas. Maka dari itu, perancangan atau pembuatan sistem inspeksi yang sudah terkomputerisasi baik dilakukan guna efisiensi waktu.

Macro adalah operasi atau sekumpulan operasi yang digunakan untuk otomatisasi suatu tugas yang dapat mengefesiensikan waktu suatu pekerjaan. Macro merupakan salah satu fitur yang terdapat pada program Microsoft Excel, serta dijalankan dengan bahasa pemrograman Visual Basic for Application (VBA). Sistem informasi dengan menggunakan Macro VBA Excel akan mempermudah dokumentasi data sehingga informasi akan menjadi lebih cepat, terpadu, presisi dan mudah diperoleh dibandingkan dengan sistem manual (Putri et al., 2013; Sobatnu \& Arfan, 2012). Aplikasi ini juga mudah dan murah untuk digunakan (Khozarisma \& Yuliani, 2018).

PT. Meidoh Indonesia (PTMI) merupakan perusahaan manufaktur yang memproduksi baut (high tension bolt), perusahaan ini terletak di Kawasan Industri Surya Cipta, Kab. Karawang, Jawa Barat. Sebagai perusahaan yang bergerak dibidang manufaktur, PT. Meidoh Indonesia melakukan pengendalian kualitas produk dengan melakukan serangkaian pemeriksaan kualitas. Banyak metode yang mengatur atau membahas mengenai kualitas dengan karakteristiknya masing-masing (Ilham, 2012). Departemen yang melakukan aktivitas pengendalian kualitas produk baut PT. Meidoh Indonesia dilakukan oleh Departemen Quality, dimana salah satu fungsi departemen ini adalah melakukan inspeksi atau pemeriksaan akhir.

Pemeriksaan di PT. Meidoh Indonesia sebelumnya melakukan pencatatan manual, yaitu operator akan menggunakan alat ukur tertentu dan setelah hasil dari pengukuran diketahui, maka operator akan mencatat hasil pengukuran pada check sheet yang sudah disiapkan. Baru-baru ini, Departemen Quality PT. Meidoh Indonesia melakukan penyesuaian dengan membuat sistem inspeksi digital menggunakan aplikasi berbasis VBA Macro Excel. Sistem inspeksi tersebut berguna untuk mempercepat proses inspeksi oleh operator dan memungkinkan operator melihat drawing ataupun check sheet inspeksi tanpa mencetaknya terlebih dahulu. Jadi melalui aplikasi ini, selain dapat mengurangi waktu proses inspeksi, tetapi juga dapat mengurangi penggunaan kertas pada proses inspeksi akhir.

Permasalahan di departemen quality yaitu lamanya waktu inspeksi pada proses inspeksi akhir, selain itu program perusahaan dalam efisiensi penggunaan kertas merupakan masalah yang dihadapi lainnya. Proses pemeriksaan akhir membutuhkan lembar check sheet yang harus dicetak pada kertas tiap satuan lot yang akan diperiksa. Maka dari itu, diperlukan sebuah analisa untuk melakukan perancangan dan pengembangan sistem inspeksi digital dengan metode FMEA berbasis Macro VBA Excel pada proses pemeriksaan akhir Departemen Quality PT. Meidoh Indonesia.

Perancangan sistem ini akan dianalisis dalam resiko yang mungkin terjadi apabila inspeksi dilakukan secara manual. Analisis resiko atau metode yang dipakai adalah Failure Mode and Effects Analysis (FMEA). Analisis FMEA bertujuan untuk mengidentifikasi dan menilai resiko-resiko yang berhubungan dengan potensi kegagalan (Iswanto et al., 2013).

Teknik FMEA merupakan yang paling pertama dikenalkan untuk melakukan analisis kesalahan (failure) pada suatu proses. Metode ini dilakukan dengan memberikan rating pada severity, occurance, dan detection sehingga menghasilkan RPN. Nilai RPN tertinggi digunakan untuk mengetahui jenis waste mana yang memiliki potensi penyebab kegagalan yang tertinggi sehingga perlu untuk dilakukan rekomendasi perbaikan terlebih dahulu (Rosih et al., 2006).

Penelitian yang dilakukan Septiani et al., (2017) menggunakan metode FMEA untuk merancang sistem pakar. Sistem pakar ini secara garis besar bekerja dengan mengidentifikasi kegagalan dalam sebuah proses menggunakan aturan IF THEN rule. Sistem ini dimulai dengan pemilihan efek yang terjadi, kemudian user akan menjawab pertanyaan iya/tidak untuk kegagalan proses, dengan mengidentifikasi penyebab kegagalan. Setelah semua pertanyaan dijawab, maka akan sistem akan merekomendasikan upaya penanggulangan dan nilai Risk Priority Number (RPN).

Berkurangnya nilai RPN maka menandakan sistem inspeksi dapat mengurangi tingkat kesalahan pada proses inspeksi akhir. Maka, berbeda dengan Septiani, penelitian ini akan menggunakan metode FMEA untuk menganalisa potensi kesalahan pada setiap uraian proses inspeksi akhir, dan dilakukan upaya perbaikan yang akan dilihat perubahan dengan berkurangnya nilai RPN pada pekerjaan inspeksi akhir. FMEA dalam penelitian ini betujuan untuk membandingkan penggunan sistem inspeksi dengan tidak menggunakan sistem inspeksi.

Proses inspeksi akhir pada pengendalian kualitas produk merupakan proses terpenting sebelum produk diterima oleh pelanggan. Pengendalian kualitas dan perbaikan proses dapat dilakukan perancangan suatu sistem yang dapat mempermudah dalam mengidentifikasi kegagalan (Septiani et al., 2017). Perancangan sistem inspeksi ini selain mempermudah dalam pencatatan dan identifikasi kecacatan dalam produk, juga dapat mengurangi penggunaan kertas sesuai yang sejalan dengan program perusahaan saat ini. Maka, tujuan dari penelitian ini untuk mengetahui proses inspeksi akhir, mengidentifikasi dan analisis FMEA pada proses pemeriksaan akhir.

\section{Metode Penelitian}

Menurut Sugiyono (2015), terdapat beberapa macam desain eksperimen, diantaranya pre expremintal 
design. Model eksperimen sendiri dilakukan dengan memberikan treatment tertentu pada suatu kelompok yang selanjutnya dilakukan observasi terhadap hasil eksperimen. One-shot case study merupakan metode penelitian pre experimental dalam hal ini membandingkan nilai RPN sebelum menggunakan sistem inspeksi dibandingkan dengan setelah menggunakan sistem inspeksi.

Penelitian ini melakukan pengembangan sistem inspeksi menggunakan Metode Failure Mode and Effects Analysis (FMEA). Uraian dari metode ini diantaranya sebagai berikut:

Studi lapangan dilakukan di PT. Meidoh Indonesia yaitu dengan melakukan magang selama satu bulan untuk mengetahui permasalahan khususnya pada departemen quality. Selain itu, dilakukan juga pengamatan pada proses inspeksi akhir (final inspection) yang dilakukan pada produk baut. Pada tahap ini nantinya akan diketahui permasalahan praktis dalam perusahaan yang dapat diperbaiki, kemudian perancangan sistem dengan menggunakan Macro VBA Excel.

Pengumpulan data dengan melakukan pengamatan serta wawancara pada leader QC departemen quality untuk mengidentifikasi proses dalam pekerjaan dan rating pada severity, occurrence dan control pada metode FMEA.

Pengolahan data dilakukan dengan menggunakan software Microsoft Excel untuk melakukan perhitungan maupun perancangan sistem. Pertama, analisis data dilakukan dengan menggunakan metode FMEA yaitu dengan menghitung RPN dan identifikasi perbaikan yang dapat dilakukan. Kedua, yaitu menggunakan penjelasan deskriptif dari sistem inspeksi yang dirancang.

\section{Hasil dan Pembahasan}

Proses pengendalian kualitas pada produk di PT. Meidoh Indonesia terdapat empat jenis pemeriksaan dari receiving hingga shipping produk. Adapun empat jenis inspeksi yang dilakukan Departemen Quality PT. Meidoh Indonesia, yaitu:

1. Incoming material

2. Acceptance Inspection/Outsourcing

3. Sorting/Visual Check

4. Final Inspection

Final inspection atau pemeriksaan akhir dilakukan oleh operator QC. Pemeriksaan akhir dilakukan dengan mengukur dan uji coba pada beberapa sampel baut dari setiap lot produk. Pengukuran dan uji coba disesuaikan dengan drawing dan syarat lulus uji yang telah ditentukan oleh customer ataupun departemen quality.

Prosedur dalam melakukan inspeksi akhir adalah sebagai berikut:

1. Operator melakukan pengambilan part dari after sorting. Pada tahap ini, operator menerima Kanban dari hasil sorting sebelumnya.

2. Operator mengambil inspection record atau check sheet dan keterangan Part Inspection Standard (PIS)
3. Operator melakukan proses inspeksi, yaitu dengan mengukur dan melakukan pemeriksaan part sesuai dengan PIS yang digunakan. Produk hasil pemeriksaan dikelompokkan berdasarkan kualitasnya, OK atau Not Good (NG). Pada proses ini, operator juga melakukan pencatatan inspeksi pada check sheet yang tersedia.

4. Operator menyerahkan hasil inspeksi kepada supervisor. Pada tahap ini, supervisor akan menerima hasil inspeksi dari operator inspeksi, untuk selanjutnya dilakukan verifikasi kepada leader QC.

5. Leader melengkapi Sample Data Sheet (SDS) yang merupakan dokumen pendukung saat part dikirim kepada customer.

\section{Analisis Failure Mode and Effects Analysis (FMEA)}

Langkah pertama dalam analisis FMEA adalah mengidentifikasi proses dalam pekerjaan seperti yang ditunjukkan dalam Tabel 1.

Tabel 1. Proses pada Final Inspection

\begin{tabular}{|l|c|c|}
\hline \multicolumn{1}{|c|}{ Nama Proses } & Kode & $\begin{array}{c}\text { Penanggun } \\
\text { g Jawab }\end{array}$ \\
\hline $\begin{array}{l}\text { Melakukan pengambilan part } \\
\text { dari after sorting }\end{array}$ & P1 & Operator \\
\hline $\begin{array}{l}\text { Mengambil IR dan PIS sesuai } \\
\text { dengan Kanban }\end{array}$ & P2 & Operator \\
\hline Melakukan inspeksi & P3 & Operator \\
\hline Menata hasil inspeksi & P4 & QC \\
\hline $\begin{array}{l}\text { Menyerahkan hasil kepada } \\
\text { Spv. QC }\end{array}$ & P5 & QC \\
\hline Melakukan verifikasi & P6 & Leader \\
\hline Melengkapi sampel data sheet & P7 & Leader \\
\hline
\end{tabular}

Tahap selanjutnya yaitu menganalisa failure atau kesalahan yang mungkin terjadi pada setiap proses, serta failure effect yang akan terjadi dari setiap kesalahan seperti yang terlihat pada Tabel 2. Pada tahap ini pengumpulan data dilakukan wawancara dan kuesioner kepada leader QC. Langkah selanjutnya yaitu pemberian rating dengan skala Likert 1-10 pada setiap failure yang mungkin terjadi di tiap proses final inspection. Penilaian atau rating failure mode dan effect ini berdasarkan kriteria severity, kriteria occurrence dan kriteria detection pada Tabel 3, 4 dan 5. Hasil pemberian rating pada setiap kriteria dicatat pada 'SEV', 'OCC' dan 'DET' seperti terlihat pada Tabel 6 yang kemudian dikalikan ketiga rating $\mathrm{SEV} \times \mathrm{OCC} \times \mathrm{DET}$ tersebut untuk menghasilkan nilai Risk Priority Number (RPN).

Tabel 2. Proses dan Failure yang Mungkin Terjadi

\begin{tabular}{|c|c|c|}
\hline $\begin{array}{c}\text { Kode } \\
\text { Proses }\end{array}$ & Failure Mode & Failure Effect \\
\hline P1 & $\begin{array}{c}\text { Kesalahan mengambil } \\
\text { part }\end{array}$ & Double inspeksi \\
\hline P2 & $\begin{array}{c}\text { PIS dan IR tidak } \\
\text { ditemukan pada } \\
\text { bantek box }\end{array}$ & Delay inspeksi \\
\hline
\end{tabular}




\begin{tabular}{|c|c|l|}
\hline $\begin{array}{c}\text { Kode } \\
\text { Proses }\end{array}$ & Failure Mode & \multicolumn{1}{|c|}{ Failure Effect } \\
\hline P3 & $\begin{array}{c}\text { Kesalahan dalam } \\
\text { metode pengecekan }\end{array}$ & Part NG terkirim \\
\hline P4 & $\begin{array}{c}\text { Hasil inspeksi tidak } \\
\text { tercatat }\end{array}$ & $\begin{array}{l}\text { Leader melakukan } \\
\text { teguran kepada } \\
\text { operator dan } \\
\text { melakukan } \\
\text { verifikasi ulang }\end{array}$ \\
\hline P5 & $\begin{array}{c}\text { IR tidak di area } \\
\text { bantek box Leader }\end{array}$ & $\begin{array}{l}\text { Leader melakukan } \\
\text { teguran dan } \\
\text { verifikasi ulang }\end{array}$ \\
\hline P6 & $\begin{array}{c}\text { Lolos double check } \\
\text { bermasalah }\end{array}$ \\
\hline P7 & $\begin{array}{c}\text { Data tidak sesuai } \\
\text { standar yang ada di } \\
\text { SDS }\end{array}$ & $\begin{array}{l}\text { Komplain dari } \\
\text { customer }\end{array}$ \\
\hline
\end{tabular}

Tabel 4. Occurance Rating

\begin{tabular}{|c|c|c|}
\hline Kemungkinan kesalahan & Periode Waktu & Ranking \\
\hline \multirow{2}{*}{$\begin{array}{l}\text { Sangat tinggi: kesalahan yang tidak dapat } \\
\text { dihindarkan }\end{array}$} & $>1 /$ hari & 10 \\
\hline & Sekali per 3-4 hari & 9 \\
\hline \multirow{2}{*}{$\begin{array}{l}\text { Tinggi: biasanya berhubungan dengan proses } \\
\text { serupa yang sering terjadi kesalahan }\end{array}$} & Seminggu sekali & 8 \\
\hline & Sebulan sekali & 7 \\
\hline \multirow{3}{*}{$\begin{array}{l}\text { Sedang: biasanya berhubungan dengan } \\
\text { proses yang mirip namun namun dalam } \\
\text { tingkat wajar }\end{array}$} & 3 bulan sekali & 6 \\
\hline & 6 bulan sekali & 5 \\
\hline & $\begin{array}{l}\text { sekali dalam } \\
\text { setahun }\end{array}$ & 4 \\
\hline $\begin{array}{l}\text { Rendah: kesalahan yang jarang terjadi dalam } \\
\text { proses yang mirip }\end{array}$ & $\begin{array}{l}\text { Sekali dalam 1-3 } \\
\text { tahun }\end{array}$ & 3 \\
\hline $\begin{array}{l}\text { Sangat rendah: hanya kesalahan yang hampir } \\
\text { mirip dengan proses yang identik }\end{array}$ & $\begin{array}{l}\text { Sekali dalam 3-6 } \\
\text { tahun }\end{array}$ & 2 \\
\hline $\begin{array}{c}\text { Sangat sedikit: Kesalahan yang sangat jarang } \\
\text { terjadi. Tidak ada kemiripan dalam proses } \\
\text { yang identik }\end{array}$ & $>7$ tahun sekali & 1 \\
\hline
\end{tabular}

Tabel 3. Severity Rating

\begin{tabular}{|c|c|c|}
\hline Efek & Kriteria: Severity & Ranking \\
\hline $\begin{array}{c}\text { Sangat } \\
\text { Berbahaya }\end{array}$ & $\begin{array}{c}\text { Menyebabkan kehilangan pelanggan, kerugian, atau } \\
\text { gangguan utama- tanpa peringatan }\end{array}$ & 10 \\
\hline Berbahaya & $\begin{array}{c}\text { Menyebabkan kehilangan pelanggan, kerugian, atau } \\
\text { gangguan utama }\end{array}$ & 9 \\
\hline $\begin{array}{c}\text { Sangat } \\
\text { tinggi }\end{array}$ & $\begin{array}{c}\text { Gangguan utama dalam pelayanan terhadap interaksi } \\
\text { kepada pelanggan, menyebabkan rework atau } \\
\text { ketidaknyamanan }\end{array}$ & 8 \\
\hline Tinggi & $\begin{array}{c}\text { Gangguan kecil dalam pelayanan terhadap interaksi } \\
\text { kepada pelanggan, menyebabkan rework atau } \\
\text { ketidaknyamanan }\end{array}$ & 7 \\
\hline Sedang & $\begin{array}{c}\text { Gangguan utama dalam pelayanan tanpa interaksi } \\
\text { kepada pelanggan, menyebabkan rework atau } \\
\text { ketidaknyamanan }\end{array}$ & 6 \\
\hline Rendah & $\begin{array}{c}\text { Gangguan kecil dalam pelayanan tanpa interaksi } \\
\text { kepada pelanggan, menyebabkan rework atau } \\
\text { ketidaknyamanan }\end{array}$ & 5 \\
\hline $\begin{array}{c}\text { Sangat } \\
\text { rendah }\end{array}$ & $\begin{array}{c}\text { Gangguan kecil dalam pelayanan terhadap interaksi } \\
\text { kepada pelanggan, tanpa menyebabkan rework atau } \\
\text { ketidaknyamanan }\end{array}$ & 4 \\
\hline Kecil & $\begin{array}{c}\text { Gangguan kecil dalam pelayanan tanpa interaksi } \\
\text { kepada pelanggan, tanpa menyebabkan rework atau } \\
\text { ketidaknyamanan }\end{array}$ & 3 \\
\hline $\begin{array}{c}\text { Sangat } \\
\text { kecil }\end{array}$ & $\begin{array}{c}\text { Tanpa gangguan pelayanan kepada pelanggan dan } \\
\text { tidak menyebabkan rework atau ketidaknyamanan }\end{array}$ & 2 \\
\hline Tidak ada & Tanpa efek & 1 \\
\hline
\end{tabular}

Tabel 5. Detection Rating

\begin{tabular}{|c|l|c|}
\hline Deteksi & \multicolumn{1}{|c|}{ Kriteria kemungkinan kesalahan dapat dicegah } & Ranking \\
\hline $\begin{array}{c}\text { Hampir } \\
\text { tidak } \\
\text { mungkin }\end{array}$ & $\begin{array}{l}\text { Tanpa kontrol yang tersedia untuk mendeteksi } \\
\text { kesalahan }\end{array}$ & 10 \\
\hline $\begin{array}{c}\text { Sangat } \\
\text { jarang }\end{array}$ & $\begin{array}{l}\text { Sangat sedikit kontrol yang ada dapat mendeteksi } \\
\text { kesalahan }\end{array}$ & 9 \\
\hline Jarang & $\begin{array}{l}\text { Sedikit kontrol yang ada dapat mendeteksi } \\
\text { kesalahan }\end{array}$ & 8 \\
\hline $\begin{array}{c}\text { Sangat } \\
\text { rendah }\end{array}$ & $\begin{array}{l}\text { Sangat rendah kontrol yang ada dapat mendeteksi } \\
\text { kesalahan }\end{array}$ & 7 \\
\hline Rendah & $\begin{array}{l}\text { Rendah kontrol yang ada dapat mendeteksi } \\
\text { kesalahan }\end{array}$ & 6 \\
\hline Sedang & $\begin{array}{l}\text { Sedang kemungkinan kontrol dapat mendeteksi } \\
\text { kesalahan }\end{array}$ & 5 \\
\hline $\begin{array}{c}\text { Sedang lebih } \\
\text { tinggi }\end{array}$ & $\begin{array}{l}\text { Sedang lebih tinggi kemungkinan kontrol dapat } \\
\text { mendeteksi kesalahan }\end{array}$ & 4 \\
\hline Tinggi & $\begin{array}{l}\text { Tinggi kemungkinan kontrol dapat mendeteksi } \\
\text { kesalahan }\end{array}$ & 3 \\
\hline $\begin{array}{c}\text { Sangat } \\
\text { Tinggi }\end{array}$ & $\begin{array}{l}\text { Sangat tinggi kemungkinan kontrol dapat } \\
\text { mendeteksi kesalahan }\end{array}$ \\
\hline Hampir pasti & Kontrol hampir pasti mendeteksi kesalahan & 1 \\
\hline
\end{tabular}

Tabel 6. Tabel FMEA Final Inspection

\begin{tabular}{|c|c|c|c|c|c|c|c|c|}
\hline $\begin{array}{c}\text { Kode } \\
\text { Proses }\end{array}$ & Failure Mode & Failure Effect & $S E V$ & Potential Causes & $\mathrm{OCC}$ & Current Controls & DET & RPN \\
\hline P1 & $\begin{array}{l}\text { Kesalahan } \\
\text { mengambil part }\end{array}$ & Double inspeksi & 6 & $\begin{array}{l}\text { Operator tidak } \\
\text { mengikuti aturan } \\
\text { dari before sorting }\end{array}$ & 7 & $\begin{array}{l}\text { Mengambil part } \\
\text { sesuai kanban }\end{array}$ & 5 & 210 \\
\hline $\mathrm{P} 2$ & $\begin{array}{l}\text { PIS dan IR tidak } \\
\text { ditemukan pada } \\
\text { bantek box }\end{array}$ & Delay inspeksi & 5 & $\begin{array}{l}\text { Operator salah } \\
\text { menaruh PIS dan } \\
\text { IR }\end{array}$ & 7 & $\begin{array}{l}\text { Pengecekan } \\
\text { kanban pada } \\
\text { tiap proses }\end{array}$ & 3 & 105 \\
\hline P3 & $\begin{array}{l}\text { Kesalahan dalam } \\
\text { metode } \\
\text { pengecekan }\end{array}$ & Part NG terkirim & 9 & Operator baru & 5 & $\begin{array}{l}\text { Diawasi oleh } \\
\text { supervisor }\end{array}$ & 4 & 180 \\
\hline P4 & $\begin{array}{l}\text { Hasil inspeksi } \\
\text { tidak tercatat }\end{array}$ & $\begin{array}{l}\text { Leader melakukan teguran } \\
\text { kepada operator dan } \\
\text { melakukan verifikasi ulang }\end{array}$ & 5 & $\begin{array}{l}\text { Operator tidak one } \\
\text { cycle }\end{array}$ & 4 & Penerapan 5S & 4 & 80 \\
\hline P5 & $\begin{array}{l}\text { IR tidak di area } \\
\text { bantek box Leader }\end{array}$ & $\begin{array}{l}\text { Leader melakukan teguran } \\
\text { dan verifikasi ulang }\end{array}$ & 6 & $\begin{array}{l}\text { Operator terburu- } \\
\text { buru }\end{array}$ & 6 & $\begin{array}{l}\text { Kehati-hatian } \\
\text { staf }\end{array}$ & 4 & 144 \\
\hline P6 & Lolos double check & SDS akan bermasalah & 8 & $\begin{array}{l}\text { Tidak melakukan } \\
\text { checklist pada IR }\end{array}$ & 3 & $\begin{array}{l}\text { Pengecekan } \\
\text { visual secara } \\
\text { runtut }\end{array}$ & 5 & 120 \\
\hline P7 & $\begin{array}{l}\text { Data tidak sesuai } \\
\text { standar yang ada di } \\
\text { SDS }\end{array}$ & Komplain dari customer & 9 & $\begin{array}{l}\text { Kesalahan input } \\
\text { dalam inspeksi }\end{array}$ & 4 & $\begin{array}{l}\text { Pengecekan } \\
\text { visual }\end{array}$ & 5 & 180 \\
\hline
\end{tabular}


Analisis dengan diagram pareto berdasarkan nilai tertinggi seperti terlihat pada Gambar 2.

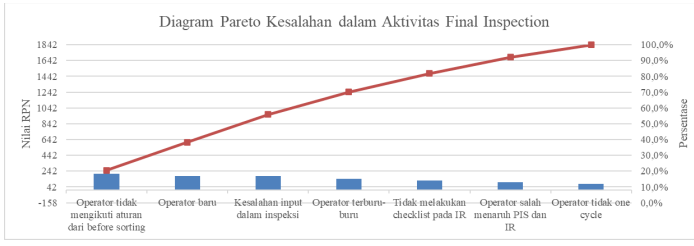

Gambar 1. Diagram Pareto Kesalahan dalam Final Inspection

Berdasarkan analisis kesalahan dan penyebab pada setiap proses, dapat dilakukan rekomendasi perlakuan pada penyebab potensial setiap kesalahan. Hal ini dilakukan untuk mengurangi tingkat atau nilai RPN dari setiap failure agar menghasilkan sistem aktivitas final inspection yang lebih baik. Rekomendasi perlakuan terlihat pada Tabel 7.

Tabel 7. Rekomendasi Perbaikan berdasarkan Analisis FMEA

\begin{tabular}{|l|l|c|c|c|c|}
\hline \multicolumn{1}{|c|}{ Potential Causes } & \multicolumn{1}{|c|}{$\begin{array}{c}\text { Action } \\
\text { Recommended }\end{array}$} & SEV & OCC & DET & RPN \\
\hline $\begin{array}{l}\text { Operator tidak } \\
\text { mengikuti aturan dari } \\
\text { before sorting }\end{array}$ & $\begin{array}{l}\text { Menggunakan } \\
\text { barcode }\end{array}$ & 6 & 4 & 3 & 72 \\
\hline Operator baru & $\begin{array}{l}\text { Gambar part yang ada } \\
\text { di dalam sistem }\end{array}$ & 5 & 6 & 2 & 60 \\
\hline $\begin{array}{l}\text { Kesalahan input } \\
\text { dalam inspeksi }\end{array}$ & $\begin{array}{l}\text { Input otomatis dari } \\
\text { alat ukur }\end{array}$ & 9 & 4 & 5 & 180 \\
\hline Operator terburu-buru & $\begin{array}{l}\text { Sistem database } \\
\text { otomatis }\end{array}$ & 5 & 4 & 2 & 40 \\
\hline $\begin{array}{l}\text { Tidak melakukan } \\
\text { checklist pada IR }\end{array}$ & $\begin{array}{l}\text { Penandaan di IR yang } \\
\text { belum/sudah diisi }\end{array}$ & 6 & 4 & 3 & 72 \\
\hline $\begin{array}{l}\text { Operator salah } \\
\text { menaruh PIS dan IR }\end{array}$ & $\begin{array}{l}\text { Tidak menggunakan } \\
\text { PIS dan IR fisik }\end{array}$ & 8 & 4 & 2 & 64 \\
\hline $\begin{array}{l}\text { Operator tidak one } \\
\text { cycle }\end{array}$ & $\begin{array}{l}\text { Sistem inspeksi yang } \\
\text { terintegrasi }\end{array}$ & 9 & 3 & 2 & 54 \\
\hline
\end{tabular}

\section{Perancangan Sistem Inspeksi}

Berdasarkan Tabel 7. diketahui bahwa nilai RPN tertinggi berada pada aktivitas kesalahan input dalam inspeksi, maka diperlukan perbaikan berupa input otomatis dari alat ukur. Perbaikan sistem sebagai upaya pengurangan kesalahan input dalam inspeksi harus menjadi prioritas perbaikan dalam perancangan sistem inspeksi.

Sistem inspeksi ini merupakan aplikasi yang dibuat untuk melakukan pencatatan inspeksi secara efisien menggunakan perangkat komputer. Tujuan dari pembuatan sistem ini yaitu untuk mengurangi pemakaian kertas dan efisensi waktu dalam melakukan pemeriksaan akhir dari tiap sampel produk. Sistem inspeksi yang digunakan oleh Departemen Quality PT. Meidoh Indonesia berupa aplikasi berbasis Macro VBA Excel dengan beberapa worksheet yang mempunyai fungsi tersendiri.
Fungsi pada worksheet ini diberikan perintah oleh bahasa pemrograman Visual Basic pada Visual Basic Editor di Tab Developer Microsoft Excel. Setiap worksheet memiliki perintah yang berbeda, sehingga menghasilkan beberapa fungsi pada satu sistem inspeksi. Worksheet atau lembar kerja tersebut antara lain:

1. Inspection Form, merupakan lembar kerja yang digunakan oleh operator untuk mencatat hasil pengukuran dan tes uji. Lembar kerja ini merupakan bagian utama dari sistem inspeksi. Secara umum, formulir isian inspection form terdapat informasi diantaranya: identitas pemeriksa, identitas part/produk, spesifikasi inspeksi, check sheet, gambar part, dan hasil inspeksi (OK/NG). Secara detail inspection form dapat dilihat pada Gambar 3.

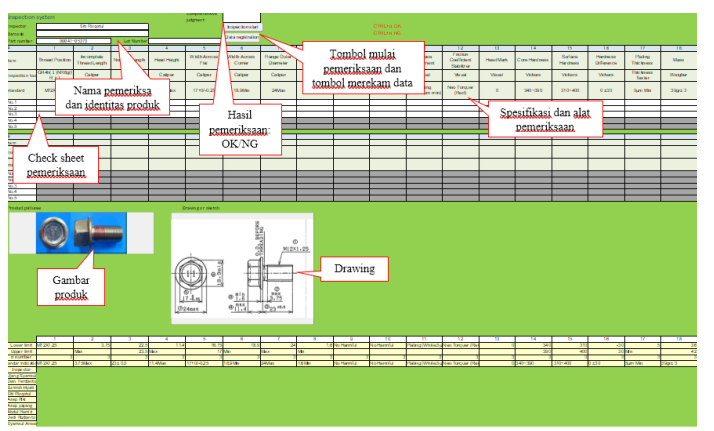

Gambar 2. Lembar kerja inspection form

2. Criteria, merupakan lembar kerja yang berfungsi sebagai database spesifikasi setiap part. Informasi yang terdapat pada lembar kerja criteria antara lain part number dan spesfikasi setiap bagian pemeriksaan. Lembar kerja ini mendapatkan input dari lembar kerja change dan outputnya merupakan informasi yang akan ditampilkan ke lembar kerja inspection form. Bentuk tampilan lembar kerja criteria dapat dilihat pada Gambar 4.

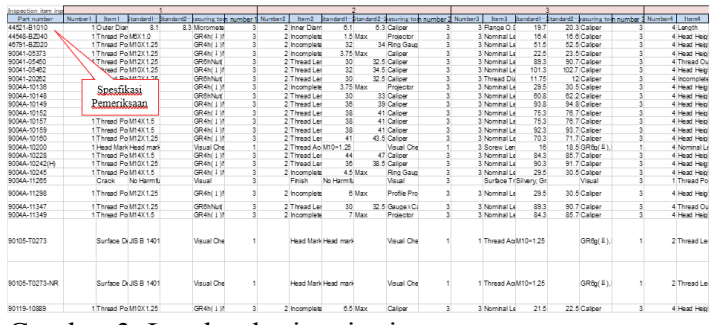

Gambar 3. Lembar kerja criteria

3. Record, merupakan lembar kerja yang mempunyai fungsi merekam data yang diinput pada lembar kerja inspection form. Data atau informasi yang terdapat dalam lembar kerja ini yaitu rincian waktu pemeriksaan, nama pemeriksa, identitas part, dan hasil check sheet. Output dari lembar kerja ini adalah pemasukan data ke dalam lembar kerja tertentu sesuai dengan laporan inspeksi tiap customer. Lembar kerja record secara visual dapat dilihat pada Gambar 5. 


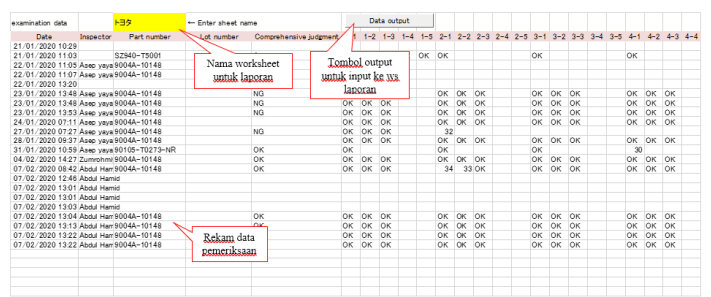

Gambar 4. Lembar kerja record

4. Report, merupakan lembar kerja yang berfungsi untuk memproses data dari record ke lembar kerja laporan inspeksi. Setiap data pada lembar kerja record akan di tentukan oleh lembar kerja ini agar data yang dihasilkan dapat terinput ke sel tertentu dalam formulir laporan inspeksi. Secara rinci, lembar kerja ini dapat dilihat pada Gambar 6.

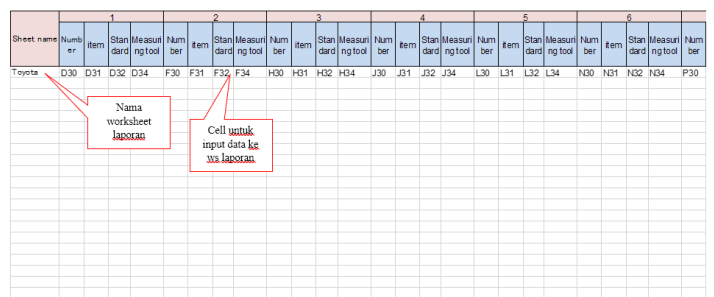

Gambar 5. Lembar kerja report

5. Change, lembar kerja ini merupakan lembar kerja formulir isian untuk memasukkan data spesifikasi part inspeksi. Setiap part yang akan diperiksa dalam sistem inspeksi ini terlebih dahulu harus diinput dalam lembar kerja ini. Hasil dari input lembar kerja ini akan masuk ke dalam lembar kerja criteria, sehingga nanti hasilnya akan terlihat dalam lembar kerja inspection form. Secara umum, dalam lembar kerja ini terdapat isian diantaranya identitas part dan spesifikasi pemeriksaan berupa ukuran, alat ukur dan banyaknya sampel. Lembar kerja change tampilannya dapat dilihat pada Gambar 7.

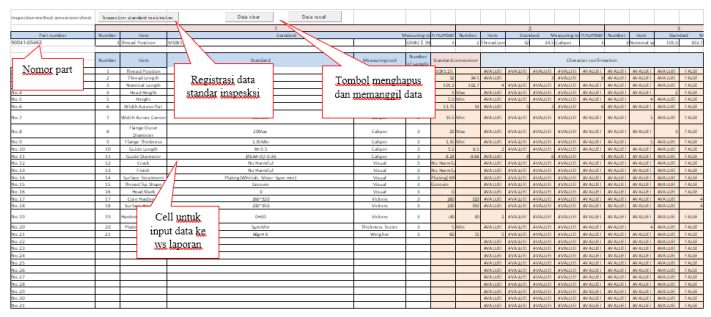

Gambar 6. Lembar kerja change

Prosedur inspeksi yang dilakukan Departemen Quality PT. Meidoh Indonesia terbagi menjadi empat macam pemerikasaan, yaitu: incoming material, acceptance inspection/outsourcing, sorting/visual check, final inspection. Pada perancangan sistem inspeksi ini, departemen quality melakukan perancangan dan pengembangan sistem terkomputerisasi untuk pekerjaan final inspection atau pemeriksaan akhir.
Pengembangan sistem inspeksi pada pekerjaan pemeriksaan akhir dapat mempersingkat waktu kerja dari operator sehingga efisiensi waktu dapat dihasilkan. Pengecekan tiap satu lot biasanya membutuhkan waktu 10 menit dapat dikurang menjadi 5 menit (tingkat efisiensi 50\%). Selain itu, penggunaan komputer dapat meminimalisir penggunaan sumber daya lain yaitu kertas sebagai check sheet untuk melakukan pekerjaan pemeriksaan akhir. Jadi dengan dirancang dan dikembangkannya sistem inspeksi ini perkerjaan telah bertransformasi dari manual yaitu tulis tangan ke sistem komputer atau digital.

Berdasarkan analisis FMEA yang telah dilakukan dengan beberapa rekomendasi perbaikan, dapat dilihat tindakan yang sudah atau belum dilakukan dari penerapan sistem inspeksi ini. Simpulan tindakan yang sudah atau belum dilakukan dapat dilihat pada Tabel 8.

Tabel 8. Tindakan Berdasarkan Hasil Analisis FMEA

\begin{tabular}{|c|l|c|c|}
\hline No & Rekomendasi Perbaikan & $\begin{array}{c}\text { Sudah } \\
\text { dilakukan }\end{array}$ & $\begin{array}{c}\text { Belum } \\
\text { dilakukan }\end{array}$ \\
\hline 1 & Menggunakan barcode & $\sqrt{ }$ & \\
\hline 2 & $\begin{array}{l}\text { Gambar part yang ada di } \\
\text { dalam sistem }\end{array}$ & $\sqrt{ }$ & \\
\hline 3 & $\begin{array}{l}\text { Input otomatis dari alat } \\
\text { ukur }\end{array}$ & $\sqrt{ }$ & \\
\hline 4 & $\begin{array}{l}\text { Sistem database } \\
\text { otomatis }\end{array}$ & $\sqrt{ }$ & \\
\hline 5 & $\begin{array}{l}\text { Penandaan di IR yang } \\
\text { belum/sudah diisi }\end{array}$ & $\sqrt{ }$ & \\
\hline 6 & $\begin{array}{l}\text { Tidak menggunakan PIS } \\
\text { dan IR fisik }\end{array}$ & $\sqrt{ }$ & \\
\hline 7 & $\begin{array}{l}\text { Sistem inspeksi yang } \\
\text { terintegrasi }\end{array}$ & $\sqrt{ }$ & \\
\hline
\end{tabular}

Perbandingan inspeksi manual dengan sistem inspeksi ini dijelaskan dalam Tabel 9.

Tabel 9. Perbandingan Inspeksi Manual dan Sistem Inspeksi

\begin{tabular}{|l|l|}
\hline \multicolumn{1}{|c|}{ Inspeksi Manual } & \multicolumn{1}{c|}{ Sistem Inspeksi } \\
\hline $\begin{array}{l}\text { Waktu pemeriksaan } \pm 10 \\
\text { menit }\end{array}$ & $\begin{array}{l}\text { Waktu pemeriksaan } \pm \\
5 \text { menit }\end{array}$ \\
\hline $\begin{array}{l}\text { Menggunakan kertas } \\
\text { check } \text { sheet }\end{array}$ & $\begin{array}{l}\text { Check } \text { sheet } \text { di dalam } \\
\text { komputer }\end{array}$ \\
\hline $\begin{array}{l}\text { Penilaian NG/OK } \\
\text { dilakukan oleh leader }\end{array}$ & $\begin{array}{l}\text { Penilaian NG/OK } \\
\text { otomatis oleh sistem }\end{array}$ \\
\hline $\begin{array}{l}\text { Tidak terdapat gambar } \\
\text { part asli }\end{array}$ & $\begin{array}{l}\text { Terdapat gambar part } \\
\text { asli }\end{array}$ \\
\hline $\begin{array}{l}\text { Pengumpulan data } \\
\text { dilakukan dengan kertas }\end{array}$ & $\begin{array}{l}\text { Pengumpulan data } \\
\text { dalam } \text { database } \text { excel }\end{array}$ \\
\hline $\begin{array}{l}\text { Output laporan harus } \\
\text { diinput Kembali }\end{array}$ & $\begin{array}{l}\text { Output laporan } \\
\text { otomatis }\end{array}$ \\
\hline $\begin{array}{l}\text { Tidak langsung terinput } \\
\text { ke } \text { server data }\end{array}$ & $\begin{array}{l}\text { Langsung berada di } \\
\text { server } \text { data }\end{array}$ \\
\hline
\end{tabular}




\section{Kesimpulan}

Proses pengendalian kualitas PT. Meidoh Indonesia memiliki 4 (empat) jenis inspeksi yang dilakukan yaitu: incoming material, acceptance inspection/outsourcing, sorting/visual check, final inspection. Final inspection atau pemeriksaan akhir prosedurnya secara umum terdiri dari pengambilan sampel produk, inspeksi oleh operator, verifikasi dan pelengkapan data sheet oleh leader QC.

Berdasarkan analisis FMEA, inspeksi manual mendapatkan nilai RPN sebesar 1019, sementara itu dengan rekomendasi perbaikan nilai RPN berkurang menjadi 542. Hal ini berarti berkurangnya resiko kesalahan pada proses pekerjaan pemeriksaan akhir. PT. Meidoh Indonesia melakukan perancangan sistem inspeksi menggunakan Macro VBA Excel dengan fungsinya antara lain inspection form, criteria, record, report dan change.

Perbandingan sebelum dan sesudah menggunakan sistem ini diantaranya: pengurangan penggunaan kertas, efisiensi waktu inspeksi akhir, dan kemudahan mengumpulkan data.

\section{Ucapan Terima Kasih}

Terima kasih kepada PT. Meidoh Indonesia karena telah mengizinkan untuk melakukan magang dan penelitian di perusahaan.

\section{Daftar Pustaka}

Handayani, E., Napitupulu, H. L., \& Siregar, I. (2013). PERANCANGAN SISTEM PENDUKUNG KEPUTUSAN PENGADAAN BAHAN BAKU PADA PD XYZ UNIT PERCETAKAN. E-Jurnal Teknik Industri FT USU, 3(4), 9-17.

Ilham, M. N. (2012). ANALISIS PENGENDALIAN KUALITAS PRODUK DENGAN MENGGUNAKAN STATISTICAL PROCESSING CONTROL ( SPC ) PADA PT . BOSOWA MEDIA GRAFIKA ( TRIBUN TIMUR). Universitas Hasanuddin Makassar.

Iswanto, A., M.Rambe, A. J., \& Ginting, E. (2013). APLIKASI METODE TAGUCHI ANALYSIS DAN FAILURE MODE AND EFFECT ANALYSIS ( FMEA ) UNTUK PERBAIKAN KUALITAS PRODUK DI PT . XYZ. E-Jurnal Teknik Industri FT USU, 2(2), 13-18.

Khozarisma, T., \& Yuliani, I. D. A. E. (2018). Perancangan Dan Pengujian Perangkat Lunak Penjadwalan Mata Pelajaran Menggunakan Algoritma Genetika. 1, 583-
593.

Lusiana, A. (2007). ANALISIS PENGENDALIAN

KUALITAS PRODUK DENGAN

MENGGUNAKAN METODE SIX SIGMA

PADA PT. SANDANG NUSANTARA UNIT

PATAL SECANG. UNIVERSITAS

NEGERI SEMARANG.

Putri, T. L. K., Santoso, P. B., \& Choiri, M. (2013). PERANCANGAN SISTEM

INFORMASI MANAJEMEN HEALTH \& SAFETY ENVIRONMENT DENGAN MENGGUNAKAN MICROSOFT EXCEL 2007 DAN MAKRO VBA ( Studi Kasus :

PT . Beiersdorf Indonesia Malang ). Jurnal Rekayasa Dan Manajemen Sistem Industri, 2(4), 750-760.

Rosih, A. R., Choiri, M., \& Yuniarti, R. (2006). Analisis risiko operasional pada departemen logistik dengan menggunakan metode FMEA. JURNAL REKAYASA DAN MANAJEMEN SISTEM INDUSTRI, 3(3), 580-591.

Sari, N. K. R., \& Purnawati, N. K. (2018). ANALISIS PENGENDALIAN KUALITAS PROSES PRODUKSI PIE SUSU PADA PERUSAHAAN PIE SUSU BARONG DI KOTA DENPASAR. EJurnal Manajemen Unud, 7(3), 1566-1594. https://doi.org/10.24843/EJMUNUD.2018.v 7.i03.p016

Septiani, W., Perdana, B. H., \& Saragih, J. (2017). PERANCANGAN SISTEM PAKAR BERBASIS FMEA UNTUK MENGIDENTIFIKASI DAN MENDIAGNOSIS RISIKO KEGAGALAN PROSES PADA PROSES PRODUKSI REAR COMBINATION E83 TRUK HINO DUTRO. Jurnal Ilmiah Teknik Industri, 5(3), 164-170.

Sobatnu, F., \& Arfan, F. (2012). OPTIMALISASI VBA MS . EXCEL UNTUK TRANSLATOR KOORDINAT UTM. Poros Teknik, 4(2), 51-56.

Sugandi, B., \& Dewi, S. (2018). Sistem Inspeksi Kecacatan pada Kaleng Menggunakan Filter Warna HSL dan Template Matching. Jurnal Ilmu Komputer Dan Informatika, 4(2), 124-130.

Sugiyono. (2015). Cara Mudah Menyusun: Skripsi, Tesis dan Disertasi. A. Nuryanto. Bandung: ALFABETA.

Sunardi, A. T. P., \& Suprianto, E. (2015). PENGENDALIAN KUALITAS PRODUK PADA PROSES PRODUKSI RIB A320 DI SHEET METAL FORMING SHOP. 
INDEPT, 5(2), 6-15.

Windarti, T. (2014). PENGENDALIAN

KUALITAS UNTUK MEMINIMASI

PRODUK CACAT PADA PROSES

PRODUKSI BESI BETON. J@Ti Undip,

9(2007), 173-180. 